\title{
Pseudodementia due to intracranial tuberculomas: an unusual presentation
}

\author{
Arvind Kumar Vaish, Nirdesh Jain, Manish Gutch, Himanshu Yadav
}

Internal Medicine Department, CSM Medical University, Lucknow, Uttar Pradesh, India

Correspondence to Professor Arvind Kumar Vaish, vaish12@rediffmail.com

\section{Summary}

Tuberculosis is highly prevalent in developing countries. Meningitis is by far the most frequent manifestation of tuberculosis in the central nervous system. Infrequently they may present as intracranial masses. Intracranial tuberculomas, either multiple or single, pose great diagnostic challenge because the appearance may resemble many other non-infectious and infectious conditions and particularly in patients without constitutional symptoms or evidence of tuberculosis elsewhere in the body. Here the author highlights an unusual presentation of intracranial tuberculomas in the form of pseudodementia where other constitutional symptoms were absent.

\section{BACKGROUND}

In developing countries, intracranial tuberculoma constitute around one-third of all intracranial masses. ${ }^{1-3}$ The developments of intracranial tuberculomas have been noted during the treatment of miliary tuberculosis or tuberculous meningitis. ${ }^{4}$ Intracranial tuberculomas may manifest ranging from asymptomatic to seizures causing compressive manifestations. It is intriguing to note that whereas on imaging there are several subcortical tuberculomas, the patient may be totally asymptomatic. Here we report a case of meningeal tuberculosis that later on developed multiple intracranial subcortical tuberculomas despite having good recovery and compliance to antituberculous therapy and now presented with pseudodementia on follow-up. Appreciation of the condition is important as appropriate treatment can lead to complete recovery in these cases.

\section{CASE PRESENTATION}

A 25-year-old, female was admitted to emergency with complaints of fever and headache for last 2 months. She also had multiple episodes of vomiting and was in delirium for 5 days. Family history was insignificant. On examination, she was febrile and other vitals were normal. Neurological evaluation revealed presence of neck rigidity and Kernig's sign. The patient was drowsy- Glasgow Coma Scale score 10 (E2M5V3). All cranial nerves were intact. Motor system and sensory examination did not reveal any abnormality. Rest of the examination was normal.

Laboratory and clinical picture was suggestive of miliary tuberculosis and tuberculous meningitis. She was started on antituberculous treatment along with prednisolone. The patient steadily improved and was discharged from hospital on day 7 and had no neurological deficit at time of discharge. The patient remained in regular followup and had visited every fortnightly and prednisolone was tapered over a period of 6 weeks. After 2 months of follow-up, her husband noticed that she had become forgetful; she did not remember things and often did not recognise him and other close relatives. On examination, at this time, the patient was relaxed; she did not appear in any distress, was slow to respond to simple commands and often kept quiet. Her recent and remote memory was impaired. Mini Mental Status Examination (MMSE) score was 17 . Prednisolone $40 \mathrm{mg}$ daily was again added to the antituberculous treatment and was followed up weekly. The patient gradually improved with addition of prednisolone and in 2 weeks her memory considerably improved. The patient continued to improve steadily and in 2 months the MMSE and Hamilton Depression Rating Scale were normal (table 1).

\section{INVESTIGATIONS}

Laboratory investigations revealed $\mathrm{Hb}-10.1 \mathrm{gm} / \mathrm{dl}$, total leucocytes count-8700/ $\mathrm{mm}^{3}$ (P79 L20 E1), platelet count$1.9 \times 10^{6} / \mathrm{mm}^{3}$, random blood sugar-98 $\mathrm{mg} / \mathrm{dl}$, serum $\mathrm{Na}^{+}-$ $137 \mathrm{meq} / \mathrm{l}$, serum $\mathrm{K}^{+}-5.1 \mathrm{meq} / \mathrm{l}$, serum urea- $17 \mathrm{mg} / \mathrm{dl}$, serum creatinine- $0.5 \mathrm{mg} / \mathrm{dl}$. Cerebrospinal fluid on examination was colorless, protein $-275.4 \mathrm{mg} / \mathrm{dl}$, sugar- $28 \mathrm{mg} /$ $\mathrm{dl}$ and total cell count- $210 / \mathrm{mm}^{3}$ (65\% polymorphs and $35 \%$ lymphocytes). Chest x-ray showed bilateral miliary mottling (figure 1). CT brain showed findings of meningoencephalitis (figure 2).

CT scan of the brain was repeated which showed multiple ring enhancing lesion with surrounding oedema in the cerebral hemiparesis (figure 3 ) suggestive of tuberculoma. Repeat CT scan done after 2 months showed healing tuberculomas (figure 4).

Table 1 MMSE and HAM-D of the patient at monthly follow-up

\begin{tabular}{lll}
\hline $\mathbf{2 0 1 1}$ & MMSE & HAM-D \\
\hline May & 17 & 25 \\
June & 20 & 15 \\
July & 22 & 9 \\
August & 24 & 4 \\
September & 27 & 2
\end{tabular}

HAM D, Hamilton Depression Rating Scale; MMSE, Mini Mental Score Examination. 


\section{BMJ Case Reports}

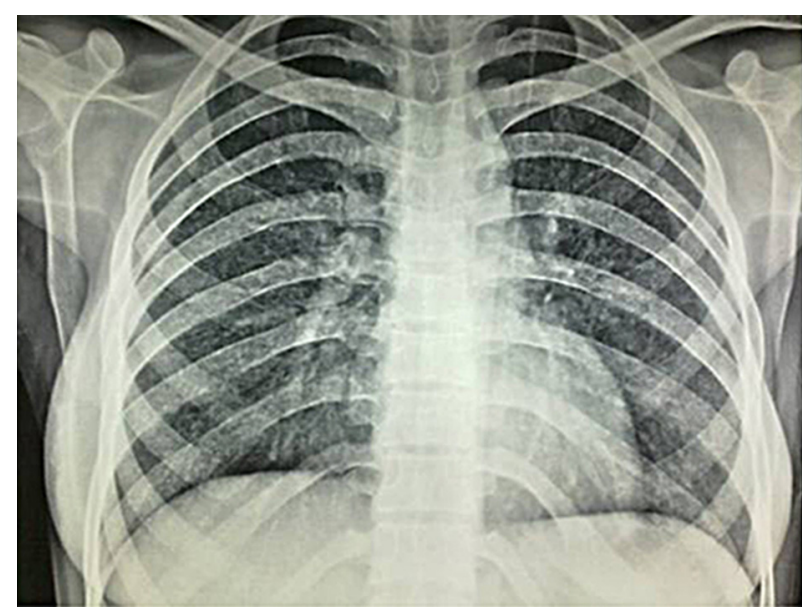

Figure 1 Chest x-ray showing miliary mottling.

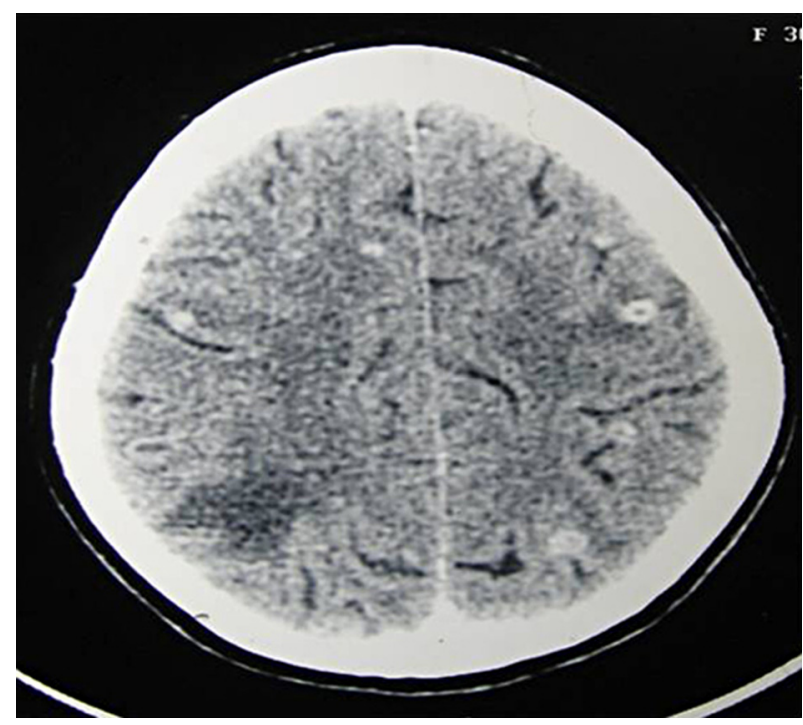

Figure 3 CT scan (done at 2 months) showing multiple ring enhancing subcortical lesions with surrounding oedema suggestive of tuberculomas.

\section{DIFFERENTIAL DIAGNOSIS}

- Hydrocephalus

- Organic brain syndrome

- Residual cortical damage and

- Sometimes depressed mood due to the cessation of prednisolone.

\section{TREATMENT}

Antituberculous treatment; a combination of Rifampicin, isoniazid, pyrazinamide and ethambutol according to her body weight along with prednisolone $40 \mathrm{mg}$ daily was started, initially. Prednisolone was tapered over a period of 6 weeks. The patient was restarted on prednisolone $40 \mathrm{mg}$ daily that was gradually tapered over a period of 8 weeks and antituberculous treatment was continued.

\section{OUTCOME AND FOLLOW-UP}

The patient has recovered and is in follow-up at monthly interval.

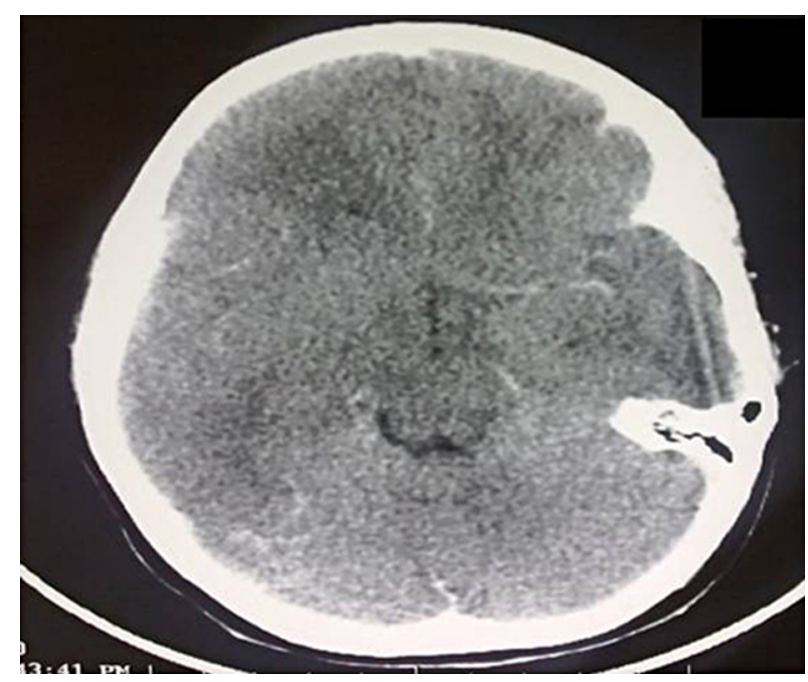

Figure 2 CT scan (at the time of admission) showing meningeal enhancement and underlying cerebral oedema (meningoencephalitis).

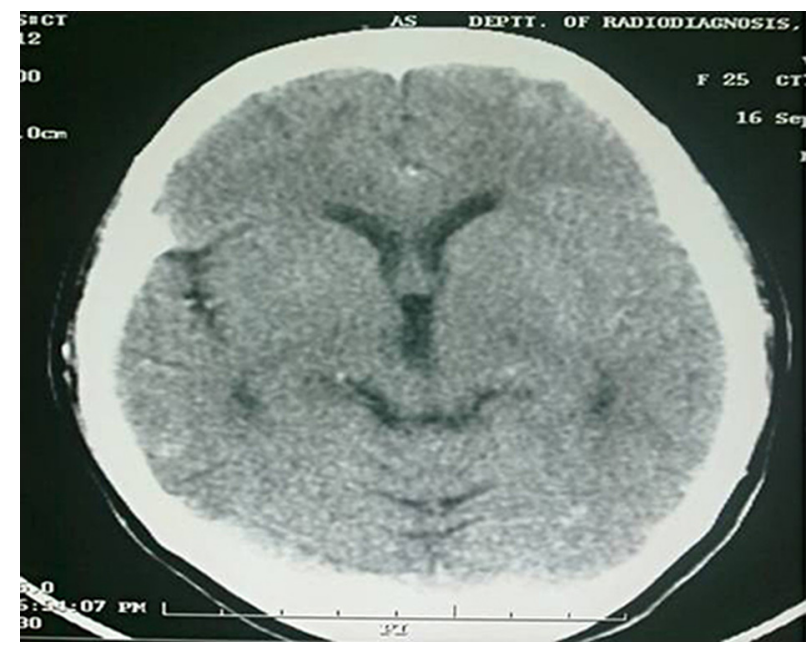

Figure 4 CT scan (done at 4 months) showing healing of tuberculomas.

\section{DISCUSSION}

Impairment of cognitive function in a young patient, one should always look for treatable causes. Our patient was on treatment for miliary tuberculosis and tuberculous meningitis. The patient was responding well to the treatment till she developed impaired cognition. In such situation, two possibilities to consider are underlying cerebral oedema or intracranial tuberculomas which may be frequently associated in such cases. Other possibilities of such complication can be hydrocephalus or drug toxicity. Thinking of cerebral oedema, she was restarted on prednisone orally. CT scan repeated at this time however showed multiple subcortical tuberculoma with surrounding oedema which was obviously responsible for the cognitive deterioration.

Tuberculomas can appear or even enlarge after initiation of antituberculous treatment and can lead to paradoxical deterioration.

The subsequent complete clinical recovery in the case confirms that the patient had pseudodementia and not true dementia. 
This case emphasises the need to keep vigil for these complications in a patient being treated for tuberculous meningitis which may cause worsening after initial improvement. Prompt diagnosis and appropriate treatment can lead to gratifying results in such cases.

\section{Learning points}

- The clinical presentation of intracranial tuberculoma is usually that of increased intracranial pressure with papilloedema and focal neurological deficits related to site of the lesion but here it is unusual that solely presented as cognitive impairment.

- Tuberculous meningitis needs regular follow-up to check drug compliance and toxicity and to catch the complications at earlier stages and to deal accordingly.

- The role of corticosteroid for tuberculous meningitis should be reconsidered and a treatment period longer than the initial 6 weeks may be warranted at least in some patients.

- Before thinking of irreversible dementia in young patients, all treatable possibilities should be ruled out.
Competing interests None.

Patient consent Obtained.

\section{REFERENCES}

1. Dolin PJ, Raviglione MC, Kochi A. Global tuberculosis incidence and mortality during 1990-2000. Bull World Health Organ 1994;72:213-20.

2. Klein NC, Damsker B, Hirschman SZ. Mycobacterial meningitis. Retrospective analysis from 1970 to 1983. Am J Med 1985:79:29-34.

3. Hejazi N, Hassler W. Multiple intracranial tuberculomas with atypical response to tuberculostatic chemotherapy: literature review and a case report. Acta Neurochir (Wien) 1997;139:194-202

4. Bas NS, Güzey FK, Emel E, et al. Paradoxical intracranial tuberculoma requiring surgical treatment. Pediatr Neurosurg 2005;41:201-5.

5. Chambers ST, Hendrickse WA, Record C, et al. Paradoxical expansion of intracranial tuberculomas during chemotherapy. Lancet 1984;2:181-4.

This pdf has been created automatically from the final edited text and images.

Copyright 2011 BMJ Publishing Group. All rights reserved. For permission to reuse any of this content visit http://group.bmj.com/group/rights-licensing/permissions.

BMJ Case Report Fellows may re-use this article for personal use and teaching without any further permission.

Please cite this article as follows (you will need to access the article online to obtain the date of publication).

Vaish AK, Jain N, Gutch M, Yadav H. Pseudodementia due to intracranial tuberculomas: an unusual presentation. BMJ Case Reports 2011;

10.1136/bcr.10.2011.4966, Published XXX

Become a Fellow of BMJ Case Reports today and you can:

- Submit as many cases as you like

- Enjoy fast sympathetic peer review and rapid publication of accepted articles

- Access all the published articles

- Re-use any of the published material for personal use and teaching without further permission

For information on Institutional Fellowships contact consortiasales@bmjgroup.com

Visit casereports.bmj.com for more articles like this and to become a Fellow 